\title{
Marmara University Medical Students' Perception on Sexual Violence against Women and Induced Abortion in Turkey
}

\author{
Nimet Emel Lüleci ${ }^{1}$, Eda Kaya ${ }^{2}$, Ece Aslan ${ }^{3}$ Ece Söylem Şenkal ${ }^{3}$, Zehra Nadide Çiçek ${ }^{3}$ \\ ${ }^{1}$ Department of Public Health, Marmara University Faculty of Medicine, İstanbul, Turkey \\ ${ }^{2}$ İstanbul University Cerrahpaşa Faculty of Medicine, İstanbul, Turkey \\ ${ }^{3}$ Marmara University Faculty of Medicine, İstanbul, Turkey
}

Background: Historically, sexual assault is a common issue in Turkey. As doctors are one of the steps to help sexually assaulted women, medical students should have basic knowledge of and sensitivity regarding this subject. Another common women's public health issue is induced abortion. In countries where access to abortion is restricted, there is a tendency towards unhealthy abortion.

Aims: The aims of this study are: (1) to determine the attitudes and opinions of Marmara University Medical Faculty students about sexual assault against women and induced abortion and (2) to propose an educational program for medical students about sexual assault and abortion.

Study Design: Cross-sectional study.

Methods: The questionnaires were self-administered and the data were analyzed using SPSS v.15.0. First, the descriptive statistics were analyzed, followed by Chisquare for contingency tests assessing differences in attitudes toward sexual assault and induced abortion by factors such as gender and educational term. Differences were considered statistically significant at $\mathrm{p}<0.05$.

Results: About $89.6 \%$ of the participants $(n=266)$ reported that they had never been sexually assaulted and about $11.5 \%$ of the women $(n=19)$ had been sexually assaulted. There was no significant relationship between previous sexual assault and gender $(\mathrm{p}>0.05)$. Although there was no significant difference regarding the extent of punishment by victim's status as a virgin, $21.3 \%(n=63)$ agreed that punishment should be more severe when the victim was a virgin. About $40.7 \%(n=120)$ agreed that the legal period of abortion in Turkey ( 10 weeks) should be longer. The majority $(86.1 \%, \mathrm{n}=255)$ agreed that legally prohibiting abortions causes an increase in unhealthy abortions.

Conclusion: An educational program on these issues should be developed for medical students.

Keywords: Abortion, knowledge, medical student, sexual assault, woman
In 2002, the World Health Organization (WHO) published a report stating that sexual violence is any sexual act committed against a person, including unwanted sexual comments or acts (1). Most sexual assaults include vaginal penetration (2).

Historically, violence against women is a common issue in Turkey, but women were not organized regarding bringing it to the public's attention until the 1980s. Their first major activity was an organized protest in support of Elimination of Discrimination against Women in the United States in 1986. In 1987, women organized the protest "Interdependence against Violence" (3). In Turkey, sexual assault was first discussed in 1989 in İstanbul during a protest intended to draw attention to

This study was presented as a poster at the $14^{\text {th }}$ Marmara Student Congress, 15-18 May 2014, İstanbul, Turkey.

Address for Correspondence: Dr. Nimet Emel Lüleci, Department of Public Health, Marmara University Faculty of Medicine, İstanbul, Turkey Phone: +90538282 2166 e-mail: emlluleci@gmail.com

Received: 10 March 2015 Accepted: 16 May 2015 •DOI: 10.5152/balkanmedj.2015.15230

Available at www.balkanmedicaljournal.org

Cite this article as:

Lüleci NE, Kaya E, Aslan E, Söylem Şenkal E, Çiçek ZN. Marmara University medical students' perception on sexual violence against women and induced abortion in Turkey.

Balkan Med J 2016;33:173-80 
the problem of sexual assault against women. After this protest, sexual assault was acknowledged and, subsequently, codified as a crime in Turkish Penal Law (4). After these protests, in 2005, the Turkish laws regarding sexual violence against women were revised in major ways. Before the changes, sexual assault had been accepted as a crime against the moral order of the family. First, a perpetrator was not punished if he agreed to marry the victim. Second, if a man killed a woman under the pressure of moral law, it was deemed a murder committed to protect his morals and he was not punished. However, the new 2005 laws reformulated these acts as crimes against personal rights and independence; morals were no longer an excusable reason to commit any crime (5).

A study of high school students conducted in 2000, in İstanbul, Turkey, found that $13.4 \%(n=250)$ of 1871 females reported that they had been sexually assaulted by touch or sexual intercourse. The same study found that the likelihood of sexual assault increased with age. The students in the sample were between the ages of 15 and 20 and the highest likelihood of sexual assault was among subjects who were 20 years old. This 2000 Turkish study of female high school students found that the perpetrators of sexual assault were overwhelmingly male; about $92.9 \%(n=196)$ of the respondents reported that sexual abuse was by a male perpetrator (6).

Intimate partner violence exists in many countries around the world. In Turkey, a study of sexual violence in marriage after the 1990s found that $71 \%$ of women had been forced to engage in sexual intercourse by their husbands (7). In a sample of 6000 men in India, researchers found that $7 \%$ of the respondents reported that they had assaulted their wives sexually and physically and $22 \%$ reported that they had assaulted their wives sexually without physical violence (8).

Another important women's public health problem is induced abortion. Induced abortion rates are about 17/1000 women in northern Europe and 18/1000 women in southern Europe (9). According to a study done in 2013, abortion rates in Turkey were $27 \%$ among women between the ages of 45 and $49,9 \%$ in those between the ages of 30 and 34 and $2 \%$ in those between the ages of 15 and $19(10)$. Access to safe abortions is an important issue because $13 \%$ of maternal deaths result from the woman's inability to access a safe abortion (11). According to a study in Turkey, in Elazı $\breve{g}, 19.7 \%$ of the women in the study ( $\mathrm{n}=82)$ preferred traditional abortion methods, such as drinking boiled quinine henna or mallow (12).

Abortion has become a popular subject in Turkey that is occasionally discussed. The results of a study in Turkey conducted in 2008 in Edirne and Tekirdağ among health college students, confirm these conservative opinions on abortion in Turkey. More than half of the respondents agreed that abortion is a moral mistake $(52.1 \%, \mathrm{n}=176)(13)$.
Between 1923 and 1965, Turkey prohibited abortion to increase its population. In 1965, new laws prohibited the termination of a pregnancy except under medical conditions, such as danger to the mother's life. Then, in 1983, women were granted the right to obtain an abortion during the first 10 weeks of a pregnancy. However, medical circumstances, for example when a mother's health is in danger, permitted induced abortion after 10 weeks. Moreover, a pregnancy resulting from rape could be terminated during the first 20 weeks (14).

The survey conducted for this study employed a questionnaire that included many questions that allow for comprehensive comparisons to other survey results. The aim of this study was to assess the Marmara University medical students' attitudes toward sexual assault against women and their perceptions of induced abortion. Respondent age, gender, place of birth, having experienced a sexual assault, acquaintanceship with someone who was sexually assaulted, and acquaintanceship with someone who had obtained an induced abortion are the explanatory variables. It is important to investigate these two women's health problems together, sexual violence and induced abortion, and with a sample of young medical students, which has not been previously done. Additionally, understanding the attitudes of this particular social group may provide sexual education and advice for the future. It is important to determine their perceptions on sexual assault and abortion because this social group intends to help people with respect to these two important topics. The results of this survey support improved health care for women in Turkey in these two areas of public health.

\section{MATERIALS AND METHODS}

\section{Data source and sampling}

This study is descriptive and cross-sectional. The data were collected between January and March of 2014 at the Başıbüyük campus of Marmara University and Marmara University Başıüyük Hospital in İstanbul, Turkey. Ethics committee approval was received for this study from the ethics committee of Marmara University Medicine Faculty. A sample of 328 students was randomly drawn from the population of all medical students ( $\mathrm{n}=900)$ enrolled at Marmara University, with a confidence interval of $98 \%$ and a $3 \%$ margin of error. Data were collected in the classrooms. Written informed consent was obtained from students who participated in this study. The questionnaires were distributed, completed by the students while the researchers waited, and then personally collected by the researchers. The respondents were free to skip any question and identifying information on the respondents 
was confidential. Some students were not able to respond because they were absent on the day of data collection $(n=30)$, and one student refused to participate. The analysis was performed on the data collected from the remaining 168 female and 129 male students $(\mathrm{n}=297)$, which is a response rate of $90.5 \%$. In the sample, 175 students $(58.9 \%)$ were in the preclinical stage of education and 122 students $(41.1 \%)$ were in the clinical stage of education. The average age was 22 , ranging from 17 to 26 -years-old.

\section{Measures}

The questionnaire included 12 questions on personal information, 14 statements about sexual assault, and 10 statements about induced abortion. The statements about sexual assault and abortion offered three response options: "agree," "neutral," or "disagree." Instead of the standard five options, three options were used to accommodate the Chi-square for contingency tests used to analyze the data. The limitations of the sample size would otherwise have resulted in too few cases in each response option cell to apply this test with confidence. The independent variables were age, gender, place of birth, student status as preclinical or clinical, residence in a large or small city, any experience of previous sexual assault, acquaintanceship with someone who had been previously sexually assaulted, and acquaintanceship with someone who had undergone an induced abortion. The dependent variables were the attitudes toward sexual assault and induced abortion.

\section{Methods of evaluation}

The data were evaluated using the statistical package Statistical Package for the Social Sciences v.15.0 (SPSS, Chicago, IL, USA). First, the descriptive statistics of the responses to the questions and statements were assessed. Then, Chi-square for contingency tests was performed to assess associations between pairs of variables. Statistical relationships were considered significant at $\mathrm{p}<0.05$ or better.

\section{RESULTS}

Table 1 presents descriptive statistics. The distributions of the responses to the statements about previous sexual assault, acquaintanceship with someone who was sexually assaulted, and acquaintanceship with someone who had undergone an induced abortion are shown in Table 1.

The questionnaire included 14 statements about sexual assault to which the respondents could respond with one of three options: "agree," "neutral," or "disagree." Table 2 shows the numerical and percentage distributions of the responses to these 14 statements.
TABLE 1. Descriptive statistics; numbers (n) and percentages (\%) of the personal information of the responders in İstanbul in $2014(\mathrm{n}=297)^{\mathrm{a}}$

\begin{tabular}{|c|c|c|}
\hline Variable & (n) & $(\%)$ \\
\hline \multicolumn{3}{|l|}{ Gender } \\
\hline Female & 168 & 56.6 \\
\hline Male & 129 & 43.3 \\
\hline Total & 297 & 100.0 \\
\hline \multicolumn{3}{|l|}{ Place of birth } \\
\hline Marmara & 147 & 50.7 \\
\hline Aegean & 12 & 4.1 \\
\hline Mediterranean & 22 & 9.3 \\
\hline Black Sea & 26 & 9.0 \\
\hline Central Anatolia & 32 & 11.0 \\
\hline South-east Anatolia & 21 & 7.2 \\
\hline East Anatolia & 15 & 5.2 \\
\hline Country other than Turkey & 10 & 3.4 \\
\hline Total & 290 & 100.0 \\
\hline \multicolumn{3}{|l|}{ Stage } \\
\hline Preclinical (1-2-3) & 175 & 58.9 \\
\hline Clinical (4-5-6) & 122 & 41.1 \\
\hline Total & 297 & 100.0 \\
\hline \multicolumn{3}{|l|}{ Residence } \\
\hline Large city & 214 & 72.8 \\
\hline Small city & 80 & 27.2 \\
\hline Total & 294 & 100.0 \\
\hline \multicolumn{3}{|l|}{ Sexual assault experience } \\
\hline Yes & 27 & 9.2 \\
\hline No & 266 & 90.8 \\
\hline Total & 293 & 100.0 \\
\hline \multicolumn{3}{|l|}{ Sexual assault acquaintance } \\
\hline Yes & 42 & 14.2 \\
\hline No & 253 & 85.8 \\
\hline Total & 295 & 100.0 \\
\hline \multicolumn{3}{|l|}{ Induced abortion acquaintance } \\
\hline Yes & 123 & 41.5 \\
\hline No & 172 & 58.5 \\
\hline Total & 295 & 100.0 \\
\hline
\end{tabular}

a: Not all totals reach $\mathrm{n}=297$ because of item non-response.

There were 10 statements in the questionnaire about induced abortion, to which the respondents could respond with one of three options: "agree," "neutral," or "disagree." Table 3 shows the numerical and percentage distributions of the responses to these 10 statements.

Most of the female $(88.5 \%, \mathrm{n}=146)$ and male respondents $(93.8 \%, n=120)$ stated that they had never been sexually assaulted and the gender difference was not statistically significant (Chi-square $=2.389, d f=1)$ (Table 4). 
TABLE 2. Distributions of responses to statements about sexual assault, numbers (n) and percentages (\%), İstanbul, $2014(\mathrm{n}=297)^{\mathrm{a}}$

Sexual assault victims should not be examined without their permission $(\mathrm{n}=297)$

\begin{tabular}{lcc}
\hline Responses $^{\mathrm{b}}$ & $(\mathrm{n})$ & $(\%)$ \\
\hline Agree & 228 & 76.8 \\
Neutral & 41 & 13.8 \\
Disagree & 28 & 9.4
\end{tabular}

Sexual assault victims should not be examined without the permission of a judicial authority $(\mathrm{n}=297)$

\begin{tabular}{lcc}
\hline Responses $^{\mathrm{b}}$ & $(\mathrm{n})$ & $(\%)$ \\
\hline Agree & 128 & 43.1 \\
Neutral & 84 & 28.3 \\
Disagree & 85 & 28.6
\end{tabular}

The doctor should inform the victim about the examination $(n=297)$

\begin{tabular}{lcc}
\hline Responses $^{\mathrm{b}}$ & $(\mathrm{n})$ & $(\%)$ \\
\hline Agree & 283 & 95.3 \\
Neutral & 9 & 3.0 \\
Disagree & 5 & 1.7
\end{tabular}

The doctor should support the victim psychologically $(n=297)$

\begin{tabular}{lcc}
\hline Responses $^{\mathrm{b}}$ & $(\mathrm{n})$ & $(\%)$ \\
\hline Agree & 278 & 93.6 \\
Neutral & 9 & 3.0 \\
Disagree & 10 & 3.4
\end{tabular}

Sexual assault always includes penetration $(n=296,1$ case was lost)

\begin{tabular}{lcc}
\hline Responses $^{\mathrm{c}}$ & $(\mathrm{n})$ & $(\%)$ \\
\hline Agree & 15 & 5.1 \\
Neutral & 29 & 9.8 \\
Disagree & 252 & 85.1
\end{tabular}

It makes the victim comfortable to start the examination somewhere besides the genitals $(\mathrm{n}=297)$

\begin{tabular}{lcc}
\hline Responses $^{\mathrm{b}}$ & $(\mathrm{n})$ & $(\%)$ \\
\hline Agree & 221 & 74.4 \\
Neutral & 48 & 16.2 \\
Disagree & 28 & 9.4
\end{tabular}

Punishment of the perpetrator should be less when the victim is a virgin $(\mathrm{n}=297)$

\begin{tabular}{lcc}
\hline Responses $^{\mathrm{b}}$ & $(\mathrm{n})$ & $(\%)$ \\
\hline Agree & 7 & 2.4 \\
Neutral & 14 & 4.7 \\
Disagree & 276 & 92.9
\end{tabular}

Punishment of the perpetrator should be more when the victim is a virgin ( $\mathrm{n}=296,1$ case was lost)

\begin{tabular}{lcc}
\hline Responses $^{\mathrm{c}}$ & $(\mathrm{n})$ & $(\%)$ \\
\hline Agree & 63 & 21.3 \\
Neutral & 38 & 12.8 \\
Disagree & 195 & 65.9
\end{tabular}

TABLE 2. Continued

Punishment of the perpetrator should be less when the victim wore a short dress $(\mathrm{n}=297)$

\begin{tabular}{lcc}
\hline Responses $^{\mathrm{b}}$ & $(\mathrm{n})$ & $(\%)$ \\
\hline Agree & 15 & 5.0 \\
Neutral & 21 & 7.1 \\
Disagree & 261 & 87.9
\end{tabular}

Sexual perpetrators are generally men ( $\mathrm{n}=296,1$ case was lost)

\begin{tabular}{lcc}
\hline Responses $^{c}$ & $(\mathrm{n})$ & $(\%)$ \\
\hline Agree & 204 & 68.9 \\
Neutral & 42 & 14.2 \\
Disagree & 50 & 16.9
\end{tabular}

I know a female sexual perpetrator ( $n=296,1$ case was lost)

\begin{tabular}{lcl} 
Responses $^{\mathrm{c}}$ & $(\mathrm{n})$ & $(\%)$ \\
\hline Agree & 56 & 18.9 \\
\hline Neutral & 39 & 13.2 \\
Disagree & 201 & 67.9
\end{tabular}

Every incidence of forced sexual activity in a marriage is a sexual assault $(\mathrm{n}=297)$

\begin{tabular}{lcc}
\hline Responses $^{\mathrm{b}}$ & $(\mathrm{n})$ & $(\%)$ \\
\hline Agree & 233 & 78.5 \\
Neutral & 47 & 15.8 \\
Disagree & 17 & 5.7
\end{tabular}

Punishment of the perpetrator should be less when the victim is a transsexual $(\mathrm{n}=297)$

\begin{tabular}{lcc}
\hline Responses $^{\mathrm{b}}$ & $(\mathrm{n})$ & $(\%)$ \\
\hline Agree & 9 & 3.0 \\
Neutral & 21 & 7.1 \\
Disagree & 267 & 89.9
\end{tabular}

Punishment of the perpetrator should be less when the victim is a prostitute $(\mathrm{n}=297)$

\begin{tabular}{lcc}
\hline Responses $^{\mathrm{b}}$ & $(\mathrm{n})$ & $(\%)$ \\
\hline Agree & 12 & 4.0 \\
Neutral & 35 & 11.8 \\
Disagree & 250 & 84.2 \\
\hline
\end{tabular}

a: Not all totals reach $n=297$ because of item non-response.

b: total $n=297 ;{ }^{\text {c: }}$ total $n=296$

The results of the Chi-square test (Table 5) found that $69.2 \%(n=148)$ of the respondents who resided in a large city agreed with the statement "An adult woman can have an abortion without permission", whereas $50.0 \%(n=40)$ of the respondents who resided in a small city agreed with this statement. The difference was statistically significant (Chisquare $=12.562, d f=2, \mathrm{p}<0.05)$.

Other results were that $69.5 \%(n=148)$ of the respondents who resided in a big city and $57.5 \%(n=46)$ of the respondents who resided in a small city agreed with the statement "Punish- 
TABLE 3. Distributions of responses to statements about abortion, numbers (n), and percentages (\%), İstanbul, $2014(\mathrm{n}=297)^{\mathrm{a}}$

The legal period of induced abortion in Turkey is 10 weeks $(n=295)$

\begin{tabular}{lcl}
\hline Responses & $(\mathrm{n})$ & $(\%)$ \\
\hline Agree & 153 & 51.9 \\
Neutral & 76 & 25.8 \\
Disagree & 66 & 22.4
\end{tabular}

An adult woman can have an abortion without permission $(n=297)$

\begin{tabular}{lcl}
\hline Responses & $(\mathrm{n})$ & $(\%)$ \\
\hline Agree & 188 & 63.3 \\
Neutral & 39 & 13.1 \\
Disagree & 70 & 23.6
\end{tabular}

A woman should have an abortion when the baby is unwanted $(n=296)$

\begin{tabular}{lcl}
\hline Responses & $(\mathrm{n})$ & $(\%)$ \\
\hline Agree & 121 & 40.9 \\
Neutral & 94 & 31.8 \\
Disagree & 81 & 27.4
\end{tabular}

A woman should have an abortion when the baby is unhealthy $(\mathrm{n}=296)$

\begin{tabular}{lcc}
\hline Responses & $(\mathrm{n})$ & $(\%)$ \\
\hline Agree & 128 & 43.2 \\
Neutral & 98 & 33.1 \\
Disagree & 70 & 23.6
\end{tabular}

A sexually assaulted woman should have the right to have an abortion at any time during her pregnancy $(\mathrm{n}=297)$

\begin{tabular}{lcc}
\hline Responses & (n) & $(\%)$ \\
\hline Agree & 165 & 55.6 \\
Neutral & 77 & 25.9 \\
Disagree & 55 & 18.5
\end{tabular}

The legal period of abortion should be longer $(n=295)$

\begin{tabular}{lcc}
\hline Responses & (n) & $(\%)$ \\
\hline Agree & 120 & 40.7 \\
Neutral & 88 & 29.8 \\
Disagree & 87 & 29.5 \\
Abortion is a sin (n 296) & & \\
Responses & (n) & $(\%)$ \\
\hline Agree & 101 & 34.1 \\
\hline Neutral & 89 & 30.1 \\
Disagree & 106 & 35.8
\end{tabular}

A woman should have her father's permission to obtain an abortion $(\mathrm{n}=295)$

\begin{tabular}{lcc}
\hline Responses & (n) & $(\%)$ \\
\hline Agree & 163 & 55.3 \\
Neutral & 70 & 23.7 \\
Disagree & 62 & 21.0 \\
An abortion ban increases unhealthy abortions (n=296) & \\
\hline Responses & $(\mathrm{n})$ & $(\%)$ \\
\hline Agree & 255 & 86.1
\end{tabular}

TABLE 3. Continued

\begin{tabular}{lll}
\hline Neutral & 19 & 6.4 \\
Disagree & 22 & 7.4
\end{tabular}

A woman's decision is more important than a man's decision regarding abortion $(\mathrm{n}=297)$

\begin{tabular}{lcc}
\hline Responses & $(\mathrm{n})$ & $(\%)$ \\
\hline Agree & 165 & 55.6 \\
Neutral & 57 & 19.2 \\
Disagree & 75 & 25.3 \\
\hline
\end{tabular}

a: Not all totals reach $\mathrm{n}=297$ because of item non-response.

TABLE 4. Relationship of gender and the experience of sexual assault, percentages with numbers of cases in parentheses $(\mathrm{n}=293)$ İstanbul, 2014

\begin{tabular}{lccc}
\hline Gender & Sexual assault & No sexual assault & Total \\
\hline Female & $11.5(19)$ & $88.5(146)$ & $100.0(165)$ \\
Male & $6.3(8)$ & $93.8(120)$ & $100.0(128)$ \\
\hline Chi-Square $=2.389(1)$ & &
\end{tabular}

TABLE 5. Relationship of place of birth and agreement with the statement:

"A woman of full legal age can have an abortion without anyone's permission"; percentages with numbers of cases in parentheses $(n=294)$ İstanbul, 2014

\begin{tabular}{lcccc}
\hline Place of birth & Agree & Disagree & Neutral & Total \\
\hline Large city & $69.2(148)$ & $18.2(39)$ & $12.6(27)$ & $100.0(214)$ \\
Small city & $50.0(40)$ & $37.5(30)$ & $12.5(10)$ & $100.0(80)$ \\
\hline $\begin{array}{l}\text { Chi-Square }=12.562(2)^{*} \\
*=p<0.05\end{array}$ & & &
\end{tabular}

TABLE 6. Relationship of place of birth and agreement with the statement: "Punishment of the perpetrator should be more severe when the victim is a virgin"; percentages with numbers of cases in parentheses ( $\mathrm{n}=293)$ İstanbul, 2014

\begin{tabular}{lcccc}
\hline Place of birth & Agree & Disagree & Neutral & Total \\
\hline Large city & $16.9(36)$ & $69.5(148)$ & $13.6(29)$ & $100.0(213)$ \\
Small city & $31.3(25)$ & $57.5(46)$ & $11.3(9)$ & $100.0(80)$ \\
\hline $\begin{array}{l}\text { Chi-Square }=7.263(2)^{* *} \\
* *=\mathrm{p}<0.01\end{array}$ & & &
\end{tabular}

ment of the perpetrator should be more severe when the victim is a virgin." The difference was statistically significant (Chisquare $=7.263, d f=2, \mathrm{p}<0.01$ ) (Table 6).

Table 7 shows that medical students' knowledge about abortion was different depending on the educational stage. The statistically significant relationship $(p<0.05)$ between educational stage and agreement with the statement "The legal period of induced abortion in Turkey is 10 weeks," shows that medical students in the clinical (more advanced) educational stage were more likely than preclinical students to answer this statement correctly ( $70.2 \%$ and $39.1 \%$, respectively). The Chi-square statistic was 33.951 ( $d f=2$ ).

The significant relationship (Chi-square $=5.171, d f=2$, $\mathrm{p}<0.05$ ) between having experienced a sexual assault and agreement with the statement "Sexual assault victims should 
TABLE 7. Relationship of student status and agreement with the statement: "The legal period for obtaining an abortion in Turkey is 10 weeks"; percentages with numbers of cases in parentheses $(n=295)$ İstanbul, 2014

\begin{tabular}{lcccc}
\hline Student status & Agree & Disagree & Neutral & Total \\
\hline Preclinical & $39.1(68)$ & $24.1(42)$ & $36.8(64)$ & $100.0(174)$ \\
Clinical & $70.2(85)$ & $19.8(24)$ & $9.9(12)$ & $100.0(121)$ \\
\hline$* * *=\mathrm{p}<0.001$ & & & &
\end{tabular}

TABLE 8. Relationship between experiencing a sexual assault and agreement with the statement: "The victim should not be examined without her or his permission," percentages with numbers of cases in parentheses $(\mathrm{n}=293)$ İstanbul, 2014

\begin{tabular}{lcccc}
\hline $\begin{array}{l}\text { Experienced } \\
\text { sexual assault }\end{array}$ & Agree & Disagree & Neutral & Total \\
\hline Sexual assault & $92.6(15)$ & $7.4(2)$ & $0.0(0)$ & $100.0(17)$ \\
No sexual assault & $75.2(200)$ & $9.8(26)$ & $15.0(40)$ & $100.0(266)$ \\
\hline $\begin{array}{l}\text { Chi-Square }=5.171(2)^{*} \\
*=\mathrm{p}<0.05\end{array}$ & & &
\end{tabular}

not be examined without their permission" shows that respondents who had experienced sexual assault were more likely than those who had not been previously sexually assaulted to agree with this statement $(92.6 \%$ in agreement, $n=25)$ (Table 8).

The relationship between having experienced a sexual assault and knowing someone who had been sexually assaulted was statistically significant $(\mathrm{p}<0.001)$ such that $94.8 \%$ $(n=239)$ of the respondents who did not know someone who had been sexually assaulted stated that they had not been sexually assaulted (Chi-square $=32.950, d f=1)$ (Table 9).

Approximately $87.7 \%(n=107)$ of the respondents who reported that they were acquainted with someone who had undergone an induced abortion agreed with the statement "An abortion ban increases unhealthy abortions" (Table 10).

\section{DISCUSSION}

A study conducted in Turkey found that $13.4 \%$ of female students $(\mathrm{n}=250)$ had been sexually assaulted (6). The study first assessed the extent of sexual assault without considering gender differences and found that $9.2 \%(\mathrm{n}=27)$ of the respondents stated that they had been sexually assaulted. Regarding gender differences, $11.5 \%(\mathrm{n}=19)$ of the women and $6.3 \%$ $(n=8)$ of the men reported an experience of sexual assault. The percentage of women was lower than that found in other studies on sexual assault against women in public.

One reason for this difference may be the educational level of respondents. The respondents in this study were university students, but the other Turkish study was conducted on high school students. This suggests that there is a negative relationship between being sexually assaulted and being well educated, so that sexual assault becomes less likely as educational
TABLE 9. Relationship between being sexually assaulted and knowing someone who had been sexually assaulted; percentages with numbers of cases in parentheses $(\mathrm{n}=291)$ İstanbul, 2014

\begin{tabular}{lccc}
\hline Acquaintance with a victim & $\begin{array}{c}\text { Experienced } \\
\text { sexual assault }\end{array}$ & $\begin{array}{c}\text { No sexual } \\
\text { assault }\end{array}$ & Total \\
\hline $\begin{array}{l}\text { Acquainted with someone } \\
\text { who was sexually assaulted }\end{array}$ & $33.3(13)$ & $66.6(26)$ & $100.0(39)$ \\
$\begin{array}{l}\text { Not acquainted with someone } \\
\text { who was sexually assaulted }\end{array}$ & $5.2(13)$ & $94.8(239)$ & $100.0(252)$ \\
\hline $\begin{array}{l}\text { Chi-Square }=32.950(1)^{* * *} \\
* * *=\mathrm{p}<0.001\end{array}$ & & & \\
\end{tabular}

TABLE 10. Relationship between knowing someone who obtained an abortion and agreement with the statement: "Abortion bans cause increases in unhealthy abortions"; percentages with numbers of cases in parentheses $(\mathrm{n}=294)$ İstanbul, 2014

\begin{tabular}{lcccc}
$\begin{array}{l}\text { Acquaintance with someone } \\
\text { who obtained an abortion }\end{array}$ & Agree & Disagree & Neutral & Total \\
\hline Acquainted & $87.7(107)$ & $5.7(7)$ & $6.6(8)$ & $100.0(122)$ \\
Not acquainted & $85.0(146)$ & $14.5(25)$ & $6.4(11)$ & $100.0(172)$ \\
\hline Chi-Square $=0.918(2) \mathrm{ns}$. & & & &
\end{tabular}

level increases. Therefore, sexual assault would be less likely among college than high school students. Another reason for this difference could be the age of the respondents. A study in 2010 found that $80 \%$ of sexually assaulted individuals were under the age of 30 and half of this $80 \%$ consisted of people younger than 18 (15). High school students are mostly younger than 18; therefore, their likelihood of being sexually assaulted would be higher than the respondents of the study.

Additionally, $68.9 \%(n=204)$ of the respondents in this study stated that sexual perpetrators are generally male. In Turkey, in a sample of female high school students, $92.9 \%(\mathrm{n}=196)$ stated that they had been sexually assaulted by a man (6). These results provide evidence that women are relatively more vulnerable to sexual assault. Thus, sexual assault is mainly a women's health problem, which points to the obligation to protect women from sexual assault and to provide gender equality.

About $65.9 \%(n=95)$ of the respondents disagreed with the statement "Punishment of the perpetrator should be more severe when the victim is a virgin." About $21.3 \%$ of the respondents $(n=63)$ agreed with that statement. Considering that Turkey is a relatively conservative country, the extent of disagreement with this statement is lower than expected. The reason for this result may be the relatively high educational level of this sample. However, this result is evidence that there are Turkish people who believe that the virginity of the victim is an important factor in sexual assault, although it runs counter to equal rights. Arguably, having engaged in sexual intercourse before marriage is not a condition that is more appropriate than virginity for sexual assault. All women should be equally protected, regardless of their sexual activity. This 
statement was important in the questionnaire to compel the respondents to ponder this moral aspect of the issue. Each student doctor should be aware of the fact that every patient deserves equal treatment. This was one of the goals of this study.

To assess the perspectives of medical students about sex workers, the statement "Punishment of the perpetrator should be less severe when the victim is a prostitute" was presented to the respondents. In a separate analysis that is not shown, about $84.2 \%(\mathrm{n}=250)$ of the respondents did not agree with the statement, but $4 \%(n=12)$ of the respondents agreed. The percentage of respondents in disagreement was lower than expected, again probably because of the relatively high educational level of the sample. This result suggests that the social status of the victim is generally not important to this sample, although it is an obligatory condition when providing health care to a victim.

This study also dealt with a moral question. About 34.1\% $(n=101)$ of the respondents agreed that it is a sin to have an abortion, whereas $35.8 \%(\mathrm{n}=105)$ of the respondents did not agree. The almost even split in the sample between considering abortion a sin or not suggests that abortion is a moral issue and dilemma. A study conducted in Edirne and Tekirdağ in 2000 among health college students found that many of the students believed that abortion is a moral mistake $(52.1 \%$, $\mathrm{n}=176$ ). This percentage is higher than that found in the current study, although the two samples are similar because they consist of university students who are about the same age. Additionally, like İstanbul, Edirne and Tekirdağ are not considered conservative provinces in Turkey. The only obvious difference between two samples is the subject matter that the respondents' study at university. Health college students study midwifery and nursing. Thus, medical students seem to be relatively more morally liberal toward abortion.

To further examine the moral aspects of the issue, another statement was presented to the respondents: "A sexually assaulted woman should have the right to have an abortion at any time in her pregnancy." In a separate analysis, it was found that slightly more than half of the respondents $(55.6 \%$, $\mathrm{n}=165$ ) agreed with the statement, which was lower than anticipated. The results suggest a dilemma. Pregnancy resulting from a sexual assault should not cause a woman to suffer from a crime that she did not commit. Women' emotions should be considered more by the people (such as the respondents in this sample) who will be providing medical attention to them.

Sexual assault and abortion are important women's public health issues in Turkey. It is important that health professionals are aware of the importance of these two subjects because health professionals encounter victims of sexual assault in need of medical attention. To support these victims, health professionals must learn about these subjects during their educational experiences. The results of this study suggest that some of the respondents may be unprepared to provide medical care to people who were sexually assaulted or who have unwanted pregnancies because of their personal moral perspectives. Thus, the results of this study are useful for identifying inadequacies in medical students.

Considering these results, an educational program for medical students can be developed. This study could be improved by obtaining data from questionnaires that have been jointly completed by respondents and researches to avoid loss of data. In this study, certain individuals did not respond to some statements, possibly because they did not fully understand the statements. This feedback from the respondents was obtained after the research was completed. Another concern with the quality of the data is the extent to which the topics of sexual assault and induced abortion are moral as well as medical and legal topics. Moreover, some people may not want to admit that they had been sexually assaulted. In addition, although this study was interested in the relationship of gender to sexual assault, aspects of sexual assault that are more male-oriented, such as perceptions of transsexuals and sexual assault, are beyond the scope of this study. Future studies may find that face-to-face interviews are more useful for collecting data on the more sensitive aspects of the topics.

In conclusion, these data suggest that an educational program on these issues should be required of medical students. At present, no such programs are available in medical schools in Turkey. However, it is important that medical students learn about sexual assault and induced abortion to avoid the negative effects that strict compliance with moral laws might have on their work during and after medical education.

Ethics Committee Approval: Ethics committee approval was received for this study from Marmara University School of Medicine Local Ethics Committee.

Informed Consent: Written informed consent was obtained from responders who participated in this study.

Peer-review: Externally peer-reviewed.

Author contributions: Concept - N.E.L., E.K., E.A., E.S.Ş., Z.N.Ç.; Design - N.E.L.; Supervision - N.E.L.; Resource - N.E.L., E.K., E.A., E.S.Ş., Z.N.Ç.; Materials - N.E.L., E.K., E.A., E.S.Ş., Z.N.Ç.; Data Collection \&/or Processing - N.E.L., E.K., E.A., E.S.Ş., Z.N.Ç.; Analysis \&/or Interpretation - N.E.L., E.K.; Literature Search - N.E.L., E.K.; Writing - N.E.L., E.K.; Critical Reviews - N.E.L., E.K.

Acknowledgements: We thank to Prof. Dr. Dilşad Save for her contributions.

Conflict of Interest: No conflict of interest was declared by the authors. 
Financial Disclosure: The authors declared that this study has received no financial support.

\section{REFERENCES}

1. Krug E, Dahlberg L, Mercy J, Zwi A, Lozano R. World report on violence and health. World Health Organization (WHO) 2002; Ch.6:149.

2. Weiss P, Zverina J. Experiences with sexual aggression within the general population in the Czech Republic. Arch Sex Behav 1999;28:265-9. [CrossRef]

3. Savran G. 80'li Yılların Kampanyaları ve Özel Alanın Politikası, Özgürlüğü Ararken: Kadın Hareketlerinde Mücadele Deneyimleri İçinde (Campaigns of 80's and politics of specialists, when we search for freedom: Experiences on struggles of women).

4. Koçali F. Mor İğnenin İzi Silinmez (Mark of Purple Needle cannot been erased). Amargi 2007;4:8-9.

5. Sarıhan Ş. Türk Ceza Kanunu Kadınlara Neler Getiriyor? (What does Turkish penal law provide to women?) Ankara, İl Özel İdaresi Genel Sekreterliği (Ankara, Secretary General of Special Provincial Administration); 2005;51-2.

6. Alikasifoglu M, Erginoz E, Ercan O, Albayrak-Kaymak D, Uysal O, Ilter O. Sexual abuse among female high school students in Istanbul Turkey. Child Abuse Negl 2006;30:247-55. [CrossRef]

7. Yavuz MF, Gölge BZ, Safran N. A survey on sexual assault in marriage. Journal of Legal Medicine 1998;3:45-50.
8. Martin SL, Kilgallen B, Tsui AO, Maitra K, Singh KK, Kupper LL. Sexual behaviour and reproductive health outcomes: Associations with wife abuse in India. JAMA 1999;282:1967-72. [CrossRef]

9. Sedgh G, Henshaw S, Singh S, Bankole A, Drescher J. Legal abortion worldwide: Incidence and recent trends. Int Fam Plan Perspect 2007;33:106-16. [CrossRef]

10. Sağlık Bakanlığı TC, Kalkınma Bakanlığı TC. (Turkish Republic Ministry of Health, Turkish Republic Ministry of Development); 2013 Türkiye Nufüs ve Sağlık Araştırması (2013 Turkey Population and Health Survey). Bölüm 2014;6:101.

11. Bilge N. Halk Sağlığı Bakışıyla Ana Çocuk Sağlığı (Mother and Child Health from the Public Health's Point of View). Bursa: Güneş-Nobel Tıp Kitabevi; 1997.

12. Sevindik F, Açık Y, Gülbayrak C, Akgün D. Elazığ İl Merkezinde Yaşayan Kadınların İstemli Düşük Yapmak Amacıyla Kullandığı Yöntemler (Abortion methods of women who live in the center of Elazığ). TSK Koruyucu Hekimlik Bülteni 2007;6:322-3.

13. Tokuç B, Berberoğlu U, Saraçoğlu G, Çelikkalp Ü. Sağlık Yüksek Okulu Öğrencilerinin Evlilik Dışı Cinsel İlişki, İstemli Düşükler ve Kontraseptif Kullanımı Hakkındaki Düşünceleri (Perceptions of health college students on extramarital sexual intercourse, abortion and use of contraceptives). Türkiye Halk Sağlığı Dergisi (Turkish Public Health Journal) 2011:170-1.

14. Çokar M. Kürtaj (Abortion). İstanbul: Babil Yayınları (Babil Publications); 2008.

15. Greenfeld AL. Sex offenses and offenders: An analysis of data on rape and sexual assault. Bureau of Justice Statistics 1997;NJC163392. 